Studia Kinanthropologica, XIX, 2018, (3), 171-181

The Scientific Journal for Kinanthropology

DIFERENCIE V POHYBOVEJ AKTIVITE, RADOSTI Z POHYBU A KVALITE ŽIVOTA ŽIAKOV A ŽIAČOK STREDNÝCH ŠKÔL S RÔZNOU ŠPORTOVOU ÚROVŇOU

\title{
DIFFERENCES IN PHYSICAL ACTIVITY, JOY OF MOVEMENT AND QUALITY OF LIFE OF PUPILS OF SECONDARY SCHOOLS WITH DIFFERENT LEVELS OF SPORT
}

\author{
J. Brodáni, N. Kováčová, L'. Šiška \& B. Páleniková \\ Univerzita Konštantína Filozofa v Nitre, Pedagogická fakulta, Katedra telesnej výchovy a športu
}

\begin{abstract}
This paper represents the differences of relationship analysis between the physical activity, joy of physical activity and the areas of quality of life in secondary school students from Spiš region in Slovakia with different sports levels. The survey was attended by the boys and girls from secondary schools with an average age 17,42 years $(\mathrm{n}=407)$. The quality of life was monitored through SQUALA questionnaire, through questionnaire PACES we monitored the joy from physical activities and the level of physical activity was examined by hours per week (PA).

Data are represented by descriptive characteristics (n, M, SD) and the significance of differences are measured by the nonparametric methods $\left(\mathrm{W}, \mathrm{U}, \mathrm{r}_{s}\right)$.

The results showed the interactions between the PA, PACES and SQUALA in secondary school students. Positive interactions prevail in group of students who perform the physical activities occasionally and actively. Minimum number of interactions we found in groups of boys and girls who perform physical activities passively. Positive interactions PA with PACES was measured only in groups of boys who performed activities occasionally $\left(\mathrm{r}_{s}=0,217 \mathrm{p}<0,10\right)$ and actively $\left(\mathrm{r}_{s}=0,214 \mathrm{p}<0,05\right)$. Positive interactions PA with areas of SQUALA we find in students who perform the physical activities occasionally (physical well-being $\mathrm{r}_{s}=0,205 \mathrm{p}<0,10$; spiritual well-being $\mathrm{r}_{s}=0,292 \mathrm{p}<0,05$ ) and actively (appearance and things ownership $\mathrm{r}_{s}=0,176 \mathrm{p}<0,10$ ). In girls group we did not find the positive interactions between PA with PACES or SQUALA.

The important relationships of PACES with SQUALA areas were recorded in groups of boys who perform the physical activities actively (physical well-being $\mathrm{r}_{s}=0,155 \mathrm{p}<0,20$; material well-being $\mathrm{r}_{s}=0,143 \mathrm{p}<0,20$ ) and in groups of girls who perform physical activities occasionally (physical wellbeing $\mathrm{r}_{s}=0,368 \mathrm{p}<0,05$;material well-being $\left.\mathrm{r}_{s}=0,226 \mathrm{p}<0,20\right)$ and passively (spiritual well-being $\mathrm{r}_{s}=0,377 \mathrm{p}<0,10$; material well-being $\left.\mathrm{r}_{s}=0,452 \mathrm{p}<0,10\right)$ or they were registered sportswomen (free time $\mathrm{r}_{s}=0,319 \mathrm{p}<0,20$ ).
\end{abstract}

Keywords: physical activity; joy; quality of life; pupils; differences

\section{SÚHRN}

Príspevok prezentuje diferencie vztahovej analýzy medzi pohybovou aktivitou, radostou z pohybu a oblastami kvality života u žiakov a žiačok stredných škôl v spišskom regióne Slovenska s rôznou športovou úrovňou.

Prieskumu sa zúčastnili chlapci a dievčatá stredných škôl v priemernom veku 17,42 rokov $(\mathrm{n}=407)$. Kvalita života bola sledovaná prostredníctvom dotazníka SQUALA, radoste z pohybových aktivít dotazníkom PACES a úroveň pohybovej aktivity v týždni v hodinách (PA). Údaje prezentujeme deskriptívnymi charakteristikami (n, M, SD) a významnost rozdielov, resp. vztahov posudzujeme neparametrickými metódami $\left(\mathrm{W}, \mathrm{U}, \mathrm{r}_{s}\right)$. 
Výsledky preukázali interakcie medzi PA, PACES a SQUALA u žiakov a žiačok stredných škôl. Pozitívne interakcie prevažujú u žiakov vykonávajúcich PA príležitostne a aktívne. Minimálny počet interakcií nachádzame v skupinách chlapcov a dievčat vykonávajúcich PA pasívne.

Pozitívne interakcie PA s PACES boli zaznamenané iba u chlapcov, ktorí vykonávali aktivity príležitostne $\left(\mathrm{r}_{s}=0,217 \mathrm{p}<0,10\right)$ a aktívne $\left(\mathrm{r}_{s}=0,214 \mathrm{p}<0,05\right)$. Pozitívne interakcie PA s oblastami SQUALA nachádzame u žiakov vykonávajúcich pohybové aktivity príležitostne (fyzická pohoda $\mathrm{r}_{s}=0,205 \mathrm{p}<0,10 ;$ spirituálna pohoda $\left.\mathrm{r}_{s}=0,292 \mathrm{p}<0,05\right)$ a aktívne (vzhlad a vlastníctvo vecí $\left.\mathrm{r}_{s}=0,176 \mathrm{p}<0,10\right)$. U dievčat nenachádzame pozitívne interakcie PA s PACES ani so SQUALA.

Významné vztahy PACES a oblastami SQUALA boli zaznamenané u skupiny chlapcov vykonávajúcich pohybové aktivity aktívne (fyzická pohoda $\mathrm{r}_{s}=0,155 \mathrm{p}<0,20$; materiálna pohoda $\mathrm{r}_{s}=0,143$ $\mathrm{p}<0,20$ ). U dievčat zasa vykonávajúcich pohybové aktivity príležitostne (fyzická pohoda $\mathrm{r}_{s}=0,368$ $\mathrm{p}<0,05$; materiálna pohoda $\mathrm{r}_{s}=0,226 \mathrm{p}<0,20$ ), pasívne (spirituálna pohoda $\mathrm{r}_{s}=0,377 \mathrm{p}<0,10$; materiálna pohoda $\mathrm{r}_{s}=0,452 \mathrm{p}<0,10$ ), resp. sú registrované športovkyne (volný čas $\mathrm{r}_{s}=0,319$ $\mathrm{p}<0,20)$.

Klưčové slová: pohyb; radoste; kvalita života; žiaci; diferencie

\section{Úvod}

Doterajšie výskumy poukazujú na pohybovú aktivitu, radosṫ z pohybu a kvalitu života ako na fenomény, medzi ktorými v procese ontogenézy adolescentov vznikajú a zanikajú interakcie (Barnet, Cliff, Morgan, Van Beurden, 2013; Brod’áni, Šiska, Kováčová, 2018ab; Šutka, 2015). Vyšší počet pozitívnych interakcií medzi spomínanými fenoménmi bolo zaznamenaných u žiakov a žiačok s dobrovolnou a organizovanou pohybovou aktivitou v týždni v rannej a neskorej adolescencii. Nízky počet interakcií pohybových aktivít s oblastami kvality života evidujeme vo výskumoch u žiakov v strednej adolescencii, resp. u žiakov stredných škôl(Bárta, Kanásová, Kalinková, Siška, 2018; Bradáčová 2012; Brod’áni 2012; Brodáni \& Paška 2014; Brod’áni, Spišiak \& Paška, 2015; Brod’áni, Lipárová \& Král, 2016; Sutka, Brod’áni, Špániková, \& Vravková, 2013).

Obdobie dospievania (adolescencie) je jedno z najtažších období života jedinca. Dochádza tu k viacerým dôležitým zmenám v biologickej, ale aj sociálnej sfére. Mení sa zjav (telesné proporcie, a pod.), názory, správanie a jednanie; celá osobnost’ prechádza premenou podobne, ako sociálne vzt̉ahy, záujmy, postoje, motivácia, životné ciele a pod. (Blatný, 2001, Valášková, Ježko,Macek,2002). Vývoj v adolescencii je charakteristický intraindividuálnou variabilitou (Antaramian, Huebner, \& Valois, 2008; Levin \& Chatters, 1998; Ojiambo, 2013).

Telesný vzhlad je dôležitou súčastou identity adolescentov. Adolescenti posudzujú a porovnávajú vlastné telo s aktuálnym štandardom atraktivity, tzn. s ostatnými adolescentmi a s ich aktuálnym ideálom. Zaoberajú sa vo velkej miere svojím telom, ide až o narcistické zameranie (Norris, 1992). Ak je adolescent so svojim telesným vzhladom spokojný, vytvára oporu pre sebavedomie a pocit, že dosiahne sociálnu akceptáciu a prestíž. Ak je znevýhodnený estetickým alebo funkčným handicapom, je riziko, že sa bude zvyšovat’ jeho neistota a negatívne sebahodnotenie. Oceňovanie vlastného zovňajšku je ovplyvnené sociálnym prostredím, ale aj „módnymi” normami a stereotypmi a do vel'kej miery je ovplyvnené telesnou zdatnostou. (Rank et al., 2014; Romanová \& Sollár, 2016 a 2017; Sigvartsen et al., 2016).

Za hlavné prínosy telesnej zdatnosti pre celkovú životnú spokojnost̉ a osobnú pohodu možno pokladat̉ nezávisloste, samostatnost’ a sebaobslužnost' jednotlivca, priaznivý vplyv na metabolizmus a schopnost' uchovat si optimálnu telesnú hmotnoste, čo d’alej ovplyvňuje výskyt a prevenciu mnohých ochorení a porúch (Kalinková, Brodáni, Kanásová, Paška, Šutka, 2015; Stevens, 2017). Adolescenti nespokojní so svojím telom sa vyznačovali nižším sebavedomím, nižším sebahodnotením, boli depresívnejší a úzkostnejší (Brod’áni, 2012). Nespokojnost’ so svojím telom je braná ako sociálna handicapovanoste, ktorá vedie aj k nižšiemu počtu priatelov (Brod’áni et al., 2015, Romanová \& Sollár, 2018). Z tohto dôvodu je odporúčané vykonávat pohybovú aktivitu minimálne 3-5x do týždňa. Množstvo a polarita interakcií pohybových aktivít s jednotlivými oblastami kvality života však úzko súvisí so špecifickostou skupín adolescentov (Brodáni et al., 2016; Gill et al., 2013).

Dôležitým faktorom, ktorý ovplyvňuje množstvo vykonávaných pohybových aktivít je aj pohlavie. Rodové rozdiely v pohybovej aktivite sú spojené s možnostłami v školskej telesnej výchove a tiež 
s príslušnými vzdelávacími potrebami, záujmami a schopnostami dievčat a chlapcov (Romanová \& Sollár, 2015 a 2016). Silnejší náklon chlapcov smerom k športu je pozorovaný hlavne z hladiska sútaživosti pričom dievčatá inklinujú viac ku aktivitám formujúcim telo a postavu ako je aerobik a pod. Toto je jednou z hlavných príčin rozdielov vo vykonávanej pohybovej aktivite (Sollár \& Romanová, 2015, 2016, 2017, 2018; Vašíčková, Groffik, Frömel, Chmelík, \& Wasowicz, 2013; Vilhjalmsson \& Kristjansdottir, 2003).

Vyššie uvádzané faktorymajú širšie pozadie. Nezanedbatel’nú úlohu však zohráva aj radost z vykonávania pohybových aktivít, ktorým sa venujú vo svojom organizovanom a volnom čase. Vysokou mierou vystupuje do popredia fenomén subjektívneho hodnotenia „radosti z pohybových aktivít”, ktorý preukazuje vysokú frekvenciu interakcií s oblastami kvality života viac ako samotný objem pohybových aktivít. Musíme však pripomenút, že stredná adolescencia prežívaná na stredných školách je vel’mi búrlivým a nestabilným obdobím, hlavne čo sa týka hodnotenia spokojnosti s kvalitou života. Napriek dostatočnej pohybovej aktivite v týždni a radosti z vykonávania pohybových aktivít nebola preukázaná dostatočná interakcia s oblastami kvality života u žiakov stredných škôl. Nízke početnosti interakcií pohybových aktivít, resp. radosti z pohybových aktivít s oblastami kvality života poukazujú na nevyhnutnost’ d’alšieho sledovania tohoto konštruktu nielen vo vztahu ku kvalite života stredoškolákov, ale aj vo vzţahu k pohlaviu, k rôznej športovej úrovni, typu strednej školy,regiónu krajiny, atd'.

\section{Ciel'}

Cielom práce je poukázat̉ na diferencie v interakciách medzi pohybovou aktivitou, radostou z pohybových aktivít a subjektívnym hodnotením oblastí kvality života u žiakov a žiačok stredných škôl s rôznou športovou úrovňouvo východoslovenskom regióne Spiš.

\section{Metodika}

Dotazníkového prieskumu zameraného na zistoovanie pohybovej aktivity v týždni, športovej úrovne, radosti z pohybovej aktivity a kvality života sa zúčastnilo 407žiakov (chlapci $n=295$, dievčatá $\mathrm{n}=112$ ) stredných škôl v Slovenskej republike v priemerom veku 17,42 roka. Medzi skupinami s rôznou športovou úrovňou neboli zaznamenané štatisticky významné rozdiely z pohlad veku.

Pohybová aktivita v týždni bola zistovaná z pohladu celkovo realizovaných hodín v týždni a hodín bez telesnej výchovy. So zvyšujúcou sa športovou úrovňou boli medzi skupinami žiakov (A-D) a žiačok (E-H) zaznamenané štatisticky významné rozdiely $(\mathrm{p}<0,01)$. Skupiny s rôznou športovou úrovňou boli zadefinované nasledovne:

Pasívni športovci $(\mathrm{A}, \mathrm{E})$ :nevyhl'adávajú pohybovú aktivitu, maximálne absolvujú povinné školské a mimoškolské športové aktivity

Príležitostní športovci (B, F):vyhladávajú pohybovú aktivitu, nepravidelnost’ v týždni, neorganizovaná pohybová aktivita;

Aktívni športovci (C, G):pravidelnost’ v týždni, nie sú členmi športovej organizácie

Registrovaní a vrcholoví športovci (D, H): sú členmi športovej organizácie, celoštátna úroveň, medzinárodná úroveň, výkonnostný alebo vrcholový šport.

Na hodnotenie radosti z pohybovej aktivity bol použitý dotazník PACES - Physical Activity Enjoyment Scale, ktorý pozostáva zo 16 výrokov, ku ktorým sa respondenti vyjadrujú na 5-bodovej Likertovej škále. Spočítaním jednotlivých odpovedí sa získa sumárne skóre. Vysoké hodnoty reprezentujú radostł z pohybovej aktivity a naopak nízke hodnoty sumárneho skóre reprezentujú prežívanie menšej radosti z pohybovej aktivity (Heesch, Masse \& Dunn, 2006).

Dotazník subjektívnej pohody obsahoval vybrané položky z dotazníka SQUALA (modifikovaný podla Dragomerická, 2006; Zannotti \& Pringuey, 1992; Ocetková, 2007, Sýkorová, 2008). Položky dotazníku boli vyhodnocované z pohladu oblastí: 1. Fyzická pohoda, 2. Psychosociálna pohoda, 3. Spirituálna pohoda, 4. Materiálna pohoda, 5. Vzdelanie, 6. Volný čas, 7. Vzhlad a vlastníctvo vecí, 8. Orientácia na budúcnost'.

Dotazník definuje oblasti z objektívnej stránky „Ako je pre teba dôležité ..." a druhá oblasti zo subjektívneho stránky „Ako si spokojná s ....". Obe položky posudzovali respondenti na 5 bodovej škále. Spokojnost’ s oblastou kvality života „Orientácia na budúcnost”” sme nevyhodnocovali vzhladom na vek. 
Pri spracovaní údajov sme použili základné deskriptívne štatistiky (početnost̉ n, priemer M, smerodajná odchýlka SD, matematický rozdiel priemerov „d”), Rozdiely medzi dôležitostou a spokojnostou $\mathrm{v}$ kvalite života u závislých skupín sme posudzovali Wilcoxonovým z testom a rozdiely medzi nezávislými skupinami sme posudzovali Mann-Whitneyovým U testom. Pri zistovaní interakcie medzi „frekvenciou pohybovej aktivity v týždni, radosti z pohybových aktivít a oblastami kvality života" sme použili Spearmanov korelačný koeficient $\left(\mathrm{r}_{s}\right)$. Pre posúdenie štatistickej významnosti rozdielov a vzţahov sme použili hladinu významnosti $\mathrm{p}<0,20$; $\mathrm{p}<0,10$; $\mathrm{p}<0,05$ a $\mathrm{p}<0,01$. Údaje boli spracované v programe MS Excel a SPSS.

\section{Výsledky}

Pohybová aktivitachlapcov a dievčat stredných škôl prerozdelených do skupín podla športovej úrovne je diferencovaná z pohladu celkového hodinového objemu pohybových aktivít $(\mathrm{p}<0,01)$ ako aj z mimoškolských pohybových aktivít v týždni $(\mathrm{p}<0,01)$. Rozdiel objemu pohybových aktivít úzko súvisí so zvyšujúcou sa športovou úrovňou (tab. 1 a 2). Pri porovnaní skupín chlapcov a dievčat s rovnakou športovou úrovňou neboli zaznamenané signifikantné rozdiely (tab. 3).

Tabulka 1./ Table 1.

Úroveř pohybovej aktivity $v$ týždni, radosti z pohybových aktivita oblastí kvality života chlapcov./ Level of physical activity in a week, thejoy of movement and the areas of quality of life- boys.

\begin{tabular}{|c|c|c|c|c|c|c|c|c|c|}
\hline & \multirow{3}{*}{ Intikatory } & \multicolumn{8}{|c|}{ Sportona üroveb chlapsi } \\
\hline & & \multicolumn{2}{|c|}{$\begin{array}{l}\text { A Paksui } \\
\text { [ar-33] }\end{array}$} & \multicolumn{2}{|c|}{$\begin{array}{l}\text { B Prilezitostui } \\
\text { [a-67] }\end{array}$} & \multicolumn{2}{|c|}{$\begin{array}{l}\text { C Mitisxi } \\
{[\mathrm{e}-104]}\end{array}$} & \multicolumn{2}{|c|}{$\begin{array}{l}\text { D Regintuovati a } \\
\text { Vicholosi [e-91] }\end{array}$} \\
\hline & & M & SD & M & SD & M & SD & M & SD \\
\hline & PA v tyzatni bez TV [B] & 1.39 & 1.71 & 3.16 & 2.00 & 5.58 & 3.33 & 8.82 & 3.50 \\
\hline & Cellowa PA v rydated [h] & 3,33 & 1.88 & 5,37 & 1.95 & 7,90 & 3,23 & $11.0 \mathrm{~s}$ & 3,49 \\
\hline & Radosf $z \mathrm{PA}$ & 55,48 & 7,69 & $\$ 6,97$ & 8,38 & 56,70 & 7,02 & 57.27 & 6,88 \\
\hline \multirow{8}{*}{ 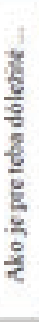 } & Fyackie poboda & 3,60 & .57 & 3.77 & .69 & 3.62 & 66 & 3.84 & 62 \\
\hline & Psychosocitha poboda & 3,49 &, 43 & 3,66 &, 53 & 3,70 & 59 & 3,66 & 54 \\
\hline & Spirstualna potoda & 3.55 & .80 & 3.78 & .79 & 3,77 & .77 & 3.77 & .71 \\
\hline & Materialna pohoda & 3.71 & .80 & 3.60 & 91 & 3.75 & 83 & 3.91 & .80 \\
\hline & Vodelanie & 3,99 & .94 & 3.63 & $8 \mathrm{t}$ & 3,58 & $\$ 0$ & 3,82 & .89 \\
\hline & Votay cas & 3,67 & .85 & 3,69 & 91 & 3,70 & 1.01 & 3,69 & 92 \\
\hline & Valad a vavaictoo veti & 3,69 & .94 & 3.61 & 90 & 3.70 & 85 & 3,65 & .78 \\
\hline & Orienticia ma botucnost & 3.55 & 97 & 3,68 & .85 & 3.67 & 1.00 & 3,72 & .88 \\
\hline \multirow{7}{*}{$\frac{\frac{1}{2}}{\frac{8}{2}}$} & Fycicle poboda & 3.54 & .63 & 3.65 & 57 & 3.64 & GS & 3.58 & .70 \\
\hline & Pychonocitilea poboda & 3,44 & .52 & 3.67 & .56 & 3.52 & 59 & 3,66 & .59 \\
\hline & Spiritualna potoda & 3,44 & 64 & 3,51 & .76 & 3.51 & $\$ 4$ & 3,59 & .75 \\
\hline & Materialna poboda & 3.61 & .78 & 3.60 & $\mathscr{2}$ & 3.62 & 95 & 3,60 & .91 \\
\hline & Vadelanie & 3,74 & 1,07 & 3,72 & .88 & 3,62 & 89 & 3,75 &, 95 \\
\hline & Vofuy cas & 3,48 & .94 & 3,69 & .89 & 3.64 & .92 & 3.68 & 1,03 \\
\hline & Vaflad a vineacho vesi & 3.56 & .78 & 3.87 & .73 & 3.50 & .77 & 3.62 & .87 \\
\hline
\end{tabular}

Legenda. PA - pohybová aktivita; TV - telesná výchova, n - počet, M - priemerná hodnota, SD štandardná odchýlka; Note. PA - physical activity, TV - physical education, n - count, M - averages, SD - standard deviation

Najnižší objem pohybových aktivít v týždni sme zaznamenali v skupinách chlapcov $(\mathrm{M}=3,33$ $\mathrm{SD}=1,88)$ a dievčat $(\mathrm{M}=3,72 \mathrm{SD}=1,64)$ uvádzajúcich pasívny záujem o pohybové aktivity. Objem pohybových aktivít u pasívnych športovcov tvorili hodiny povinnej telesnej výchovy a organizovaná pohybová aktivita na stredných školách, a vo výnimočných prípadoch mimoškolská pohybová aktivita. Najvyšší objem pohybových aktivít dosahujú chlapci $(\mathrm{M}=11,08 \mathrm{SD}=3,49)$ a dievčatá $(\mathrm{M}=10,84$ $\mathrm{SD}=3,24)$, ktorí sú registrovaní v rámci športových klubov, majú vyššiu dotáciu hodín telesnej výchovy na školách, vykonávajú šport na vrcholovej úrovni, resp. majú k dispozícii väčšie množstvo volitelných krúžkov zameraných na pohybové aktivity. 
Výsledky hodnotenia radosti z pohybových aktivít medzi skupinami chlapcov a dievčat neindikujú medzi pohlaviami ani medzi zadefinovanými športovými úrovňami štatisticky významné rozdiely (tab. 3).

Tabulka 2./ Table 2.

Úroveř pohybovej aktivity $v$ týždni, radosti z pohybových aktivíta oblasti kvality života dievčat./ Level of physical activity in a week, the joy of movement and the areas of quality of life-girls.

\begin{tabular}{|c|c|c|c|c|c|c|c|c|c|}
\hline & \multirow{3}{*}{ Insteitory } & \multicolumn{8}{|c|}{ Sportova üronch dievtati } \\
\hline & & \multicolumn{2}{|c|}{$\begin{array}{c}\text { E Pasivac } \\
{[\mathrm{a}=18]}\end{array}$} & \multicolumn{2}{|c|}{$\begin{array}{c}\text { F Priletitostae } \\
\text { [or-35] }\end{array}$} & \multicolumn{2}{|c|}{$\begin{array}{c}\text { G Altivne } \\
\{\mathrm{a}=40 \mid\end{array}$} & \multicolumn{2}{|c|}{$\begin{array}{l}\text { H Registrenant a } \\
\text { Vrcholowt }|\mathrm{a}=19|\end{array}$} \\
\hline & & M & SD & M & SD & M & SD & M & SD \\
\hline & PA v tydata bez TV [B] & 1.89 & 1,37 & 2,91 & 1,98 & 6.20 & 3,57 & 8,74 & 3,30 \\
\hline & Cellkend $P A \vee$ tysdra $[\mathrm{b}]$ & 3,72 & 1,64 & 4,91 & 1,98 & 8,43 & 3,70 & 10,84 & 3,24 \\
\hline & Radoos' z PA & $\$ 8,72$ & 5.22 & $\$ 6,60$ & 6.55 & $\$ 8.08$ & 5,36 & $\$ 9,68$ & 4,74 \\
\hline \multirow{8}{*}{ 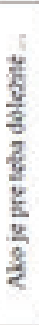 } & Fyricki poloda & 3.98 & .46 & 3.72 & 50 & 3.59 & 59 & 3.63 & 63 \\
\hline & Aychosesialna poboda & 3.64 & .41 & 3.76 & .46 & 3,63 & 43 & 3,73 & 30 \\
\hline & Spiritustina potoda & 3,50 & .65 & 3,71 & .73 & 3,56 & .65 & 3,64 & $\$ 2$ \\
\hline & Mencrialea pothodt & 3.39 & .65 & 3,69 & 1.01 & 3.90 & .86 & 3.76 & 95 \\
\hline & Vadelanic & 3.64 & .70 & 3.50 & .76 & 3.64 & 95 & 3.58 & 99 \\
\hline & Vollug cas & 3,78 & .71 & 3.81 & 1.01 & 3,35 & 98 & 3,58 & 69 \\
\hline & Vulfad a vlastriktro veci & 3.55 & .78 & 3,79 & $\$ 0$ & 3,39 & .83 & 3,61 & 1,02 \\
\hline & Orientikia na butucroot' & 3,36 & .85 & 3.79 & .77 & 3.54 & 1.02 & 3.53 & .70 \\
\hline \multirow{7}{*}{$\begin{array}{l}\frac{3}{2} \\
\frac{1}{5} \\
\frac{5}{2} \\
\frac{g}{2} \\
\frac{2}{2} \\
\frac{g}{2}\end{array}$} & Fyridua posoda & 3.61 & $\$ 2$ & 3.62 & .71 & 3.42 & 55 & 3,77 & 37 \\
\hline & Puschovecialna poboda & 3.69 & .39 & 3,71 & 47 & 3.56 & 52 & 3.68 & +40 \\
\hline & Spininustina pothoda & 3.17 &, 69 & 3,59 & .77 & 3,55 & .75 & 3,59 &, 42 \\
\hline & MEnerinlsa pobots & 3.44 & 91 & 3,87 & 83 & 3.38 & 97 & 3,47 & .77 \\
\hline & Vadelanie & 3.83 & .71 & 3.83 & 87 & 3.54 & 92 & 3.53 & 68 \\
\hline & Voltry cas & 3.56 & 1.06 & 3,79 & 1.00 & 3.73 & .88 & 3.53 & 84 \\
\hline & Valfad a vlastnictio reci & $3.6 \mathrm{t}$ & .62 & 3,71 & 69 & 3,66 & .74 & 3,54 & 85 \\
\hline
\end{tabular}

Legenda. PA - pohybová aktivita; TV - telesná výchova, n - počet, M - priemerná hodnota, SD štandardná odchýlka; Note. PA - physical activity, TV - physical education, n - count, M - averages, $\mathrm{SD}$ - standard deviation

Porovnaním úrovne kvality života medzi skupinami chlapcov a dievčat s rôznou športovou úrovňou (tab. 1-3), resp. z pohladu subjektívneho hodnotenia dôležitosti a spokojnosti s oblastami kvality života (tab. 4), poukázalo na niektoré spoločné znaky. V skupinách chlapcov a dievčat sme nezaznamenali $\mathrm{v}$ priemere vyššie indexy hodnotiacich škál $>=4,0$ velmi dôležité, resp. $>=4,0$ spokojný (tab. 1 a 2 ).

Medzi skupinami chlapcov a dievčat s rôznou športovou úrovňou neboli zaznamenané (až na dva prípady) štatisticky významné rozdiely $(\mathrm{p}=$ n.s.) v subjektívnom hodnotení dôležitosti a spokojnosti kvality života, resp. v ich jednotlivých oblastiach (tab. 3). Významné rozdiely $(\mathrm{U}=175,5 ; \mathrm{p}=0,02)$ sme zaznamenali iba $\mathrm{v}$ hodnotení fyzickej pohody, ktorej dievčatá s pasívnou športovou úrovňou prikladajú vyššiu dôležitoste $(\mathrm{M}=3,98, \mathrm{SD}=0,46)$ ako chlapci $(\mathrm{M}=3,60, \mathrm{SD}=0,57)$. Vyššiu dôležitost' ( $\mathrm{U}=1633,0 ; \mathrm{p}=0,04)$ prikladajú oblasti vzhladu a vlastníctva vecí zasa chlapci $(\mathrm{M}=3,70$, $\mathrm{SD}=0,85)$ ako dievčatá $(\mathrm{M}=3,39, \mathrm{SD}=0,83)$ vykonávajúcich pohybové aktivity aktívne.

Kongruencia (súlad medzi realitou prežívania a postojom k tejto realite) medzi dôležitostou a spokojnostou (tab. 4) bola zaznamenaná v športových skupinách dievčat skoro vo všetkých oblastiach kvality života. Dievčatá vykonávajúce pohybové aktivity aktívne pripisujú vyššiu dôležitost iba materiálnej pohode ako sú s ňou spokojné $(\mathrm{z}=2,345 ; \mathrm{p}=0,02)$. U chlapcov bola komplexná kongruencia medzi dôležitostou a spokojnostouzaznamenaná v oblastiach vzdelania a volného času. Vyššiu dôležitost' ako spokojnost pripisujú príležitostní športovci spirituálnej pohode $(\mathrm{z}=1,935, \mathrm{p}=0,05)$, aktívny športovci psychosociálnej $(\mathrm{z}=2,703, \mathrm{p}=0,01)$ a spirituálnej pohode $(\mathrm{z}=2,571, \mathrm{p}=0,01)$, 
i registrovaní - vrcholoví športovci fyzickej $(\mathrm{z}=2,989, \mathrm{p}=0,01)$ a materiálnej pohode $(\mathrm{z}=2,356$, $\mathrm{p}=0,02)$.

Tabulka 3./ Table 3.

Štatistické porovnanie pohybovej aktivity v týždni, radosti z pohybových aktivít a oblastí kvality života medzi skupinami chlapcov a dievčat s rôznou športovou úrovňou./ Statistical comparison of physical activity in a week, the joy of movement and quality of life among the groups boys and girls with different level of sport performance.

\begin{tabular}{|c|c|c|c|c|c|c|c|c|c|}
\hline & \multirow[t]{2}{*}{ Indikitory } & \multicolumn{2}{|c|}{$\begin{array}{l}\text { Pasivzi } \\
\text { AळE }\end{array}$} & \multicolumn{2}{|c|}{$\begin{array}{l}\text { Priletifostni } \\
\text { B } \odot F\end{array}$} & \multicolumn{2}{|c|}{$\begin{array}{c}\text { Aktivni } \\
C<\in G\end{array}$} & \multicolumn{2}{|c|}{$\begin{array}{c}\text { Regiofrovania } \\
\text { Vrcholovi } \\
\text { D }>H\end{array}$} \\
\hline & & $\mathrm{U}$ & p & $v$ & $p$ & $\mathbf{v}$ & $p$ & $\mathrm{U}$ & $p$ \\
\hline & PA v rystai be: TV [L] & 227.5 & 15 & 1081.0 & 51 & 1850.5 & .90 & 845,0 & 38 \\
\hline & Celkona PA v fýshe [h] & 201.5 & .26 & 10265 & 30 & 1899.5 &, 42 & 85.0 & $s 2$ \\
\hline & Rados' = PA & 225,5 & .18 & 1125,0 & .74 & 1858,0 & 39 & 665,5 & 12 \\
\hline \multirow{8}{*}{$\begin{array}{l}\frac{y}{3} \\
\frac{3}{3} \\
\frac{3}{3} \\
\frac{z}{3} \\
\frac{3}{2} \\
\frac{8}{2} \\
\frac{3}{2}\end{array}$} & Fyzicka poboda & $175,5^{\circ}$ &, 02 & 1004.5 & 58 & 1986,0 & .67 & 609.5 & .19 \\
\hline & Psychonecitila poboda & 250.0 & 35 & tosts & .45 & 1900.0 & .42 & 752.0 & 37 \\
\hline & Spirituil'na pohoda & 280,0 & .74 & 10520 & 52 & 1725,5 &, 11 & 749.5 & 36 \\
\hline & Materialna pohoda & 231.0 & .19 & 1000.5 & 56 & 1856.0 & 31 & 79.0 & .58 \\
\hline & Vsdeletide & 295.0 & 97 & 10545 & .40 & 2010.5 & .75 & 701.0 & 32 \\
\hline & Vofing cas & 285,0 & 81 & 1054,0 & A0 & 1677,0 & 07 & 769,5 & A5 \\
\hline & Vilhad a vlastrictvo veci & 281.0 & .80 & 1034.5 & 33 & $1633,0^{\circ}$ & , 04 & 820.0 & .78 \\
\hline & Orientikia na buticnosf & 205.5 & 30 & 1102.0 & st & 1891.5 & 39 & 730.0 & .28 \\
\hline \multirow{7}{*}{$\frac{\vdots}{\frac{1}{8}}$} & Fyaicka poboda & 253.5 & 39 & 11110 & 86 & 1656,5 & 05 & 694,5 & .18 \\
\hline & Prychonocilina poboda & 206.0 & .07 & 1059.5 & 36 & 1938.0 & 53 & $\pi 8.0$ & $A 9$ \\
\hline & Spirinallna pohods & 200.5 & .26 & 1096.5 & 59 & 2031.0 & .83 & 857.5 & .0 \\
\hline & Materialna poboda & 278.5 & .71 & 946,5 & .10 & 1759.0 & 19 & 780.5 & 50 \\
\hline & Vsdelanie & 206.5 & 83 & 1094.5 & 48 & 1982.0 & .66 & 73.5 & 39 \\
\hline & Volmy cas & 286.0 & .83 & 11015 & -61 & 1974.5 & .63 & 755,5 & 38 \\
\hline & Vithad a vlastrictwo veci & 282.5 & .77 & 1000,0 & 22 & 1874,0 & 35 & 320.5 &, 73 \\
\hline
\end{tabular}

Legenda. PA - pohybová aktivita, TV - telesná výchova, Mann-Whitney U test, $\mathrm{p}<0,05 \star, \mathrm{p}<0,01 \star \star$; Note. PA - physical activity, TV - physical education, Mann-Whitney U test, $\mathrm{p}<0,05 \star, \mathrm{p}<0,01 \star \star$

Tabulka 4./ Table 4.

Štatistické porovnanie oblastí kvality života z pohladu dôležitosti a spokojnosti u chlapcov a dievčat $s$ rôznou športovou úrovňou./ Statistical comparison of the areas of quality of life in terms of importance and satisfaction in boys and girls with different level of sport performance.

\begin{tabular}{|c|c|c|c|c|c|c|c|c|c|}
\hline & \multirow{3}{*}{ Indikatory } & \multicolumn{8}{|c|}{ Športová úroveñ } \\
\hline & & \multicolumn{2}{|c|}{ Pasivni } & \multicolumn{2}{|c|}{ Priležitostni } & \multicolumn{2}{|c|}{ Aktivni } & \multicolumn{2}{|c|}{$\begin{array}{l}\text { Registrovani } \\
\text { a Vreholovi }\end{array}$} \\
\hline & & $z$ & $\mathrm{p}$ & z & p & z & p & $z$ & $\mathrm{p}$ \\
\hline \multirow{7}{*}{ 总 } & Fyzická pohoda & .227 & 82 & 1,216 &, 22 &, 014 & ,99 & $2,989 * m$ & ,01 \\
\hline & Psychosociálna pohoda &, 791 & 43 &, 062 &, 95 & $2,703^{* *}$ &, 01 &, 421 & .67 \\
\hline & Spirituálna pohoda & .713 &, 48 & $1,935 *$ &, 05 & $2,571^{* \bullet}$ &, 01 & 1,782 & .07 \\
\hline & Materiálna pohoda & 564 & 57 & .196 & .84 & .664 & .51 & $2,356 *$ & ,02 \\
\hline & Vzdelanie & 1,061 & .29 & 604 & s5 &, 280 & .78 & .704 & .48 \\
\hline & Volný čas & .841 & .40 &, 125 &, 90 &, 241 &, 81 &, 345 & .73 \\
\hline & Vzhl'ad a vlastnictvo veci & 319 & .75 & $2,059 *$ & ,04 & .857 & .39 & .350 & .73 \\
\hline \multirow{7}{*}{ 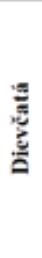 } & Fyzická pohoda & 1,806 & .07 & .974 &, 33 & 1,378 &, 17 &, 715 &, 47 \\
\hline & Psychosociálna pohoda &, 404 & .69 & .834 & .40 & .015 & .99 & .371 & .71 \\
\hline & Spirituálna pohoda & 1,641 & .10 & 649 & .52 & .090 &, 93 & .566 & 57 \\
\hline & Materiálna pohoda & .254 & 80 & 838 & .40 & $2,345 *$ &, 02 & 987 & 32 \\
\hline & Vzdelanie & .864 & 39 & 1,557 &, 12 & .550 &, 58 &, 177 & 86 \\
\hline & Volnỷ čas & 524 & .60 & .315 & .75 & 1.897 &, 06 & .211 & 83 \\
\hline & Vzhl'ad a vlastnictvo vecí & .238 & 81 & .521 & .60 & 1,527 & .13 & .405 & .69 \\
\hline
\end{tabular}

Legenda (Note). Wilcoxon $\mathrm{z}$ test, $\mathrm{p}<0,05 \star, \mathrm{p}<0,01 \star \star$ 
Výsledky preukázali interakcie medzi PA, PACES a SQUALA u žiakov a žiačok stredných škôl (tab. 5 a 6). Pozitívne interakcie prevažujú u žiakov vykonávajúcich PA príležitostne a aktívne. Minimálny počet pozitívnych interakcií nachádzame v skupinách chlapcov a dievčat vykonávajúcich pohybové aktivity pasívne, resp. v skupinách registrovaných - vrcholových športovcov.

Pozitívne interakcie pohybovej aktivity s radostou z pohybových aktivít boli zaznamenané iba $\mathrm{u}$ chlapcov, ktorí vykonávali aktivity príležitostne $\left(\mathrm{r}_{s}=0,217 \mathrm{p}=0,08\right)$ a aktívne $\left(\mathrm{r}_{s}=0,214 \mathrm{p}=0,03\right)$. Pozitívne interakcie pohybovej aktivity s oblastami kvality života nachádzame u žiakov vykonávajúcich pohybové aktivity príležitostne (fyzická pohoda $\mathrm{r}_{s}=0,205 \mathrm{p}=0,10$; spirituálna pohoda $\mathrm{r}_{s}=0,292$ $\mathrm{p}=0,02)$ a aktívne (vzhlad a vlastníctvo vecí $\left.\mathrm{r}_{s}=0,176 \mathrm{p}=0,07\right)$. U dievčat nenachádzame pozitívne interakcie PA s PACES ani so SQUALA (tab. 5).

Tabulka 5./ Table 5.

Korelácie celkovej pohybovej aktivity v týždni k radosti z pohybových aktivít a oblastiam kvality života./ Correlation of overall physical activity in a week to enjoyment from movement and areas of quality of life.

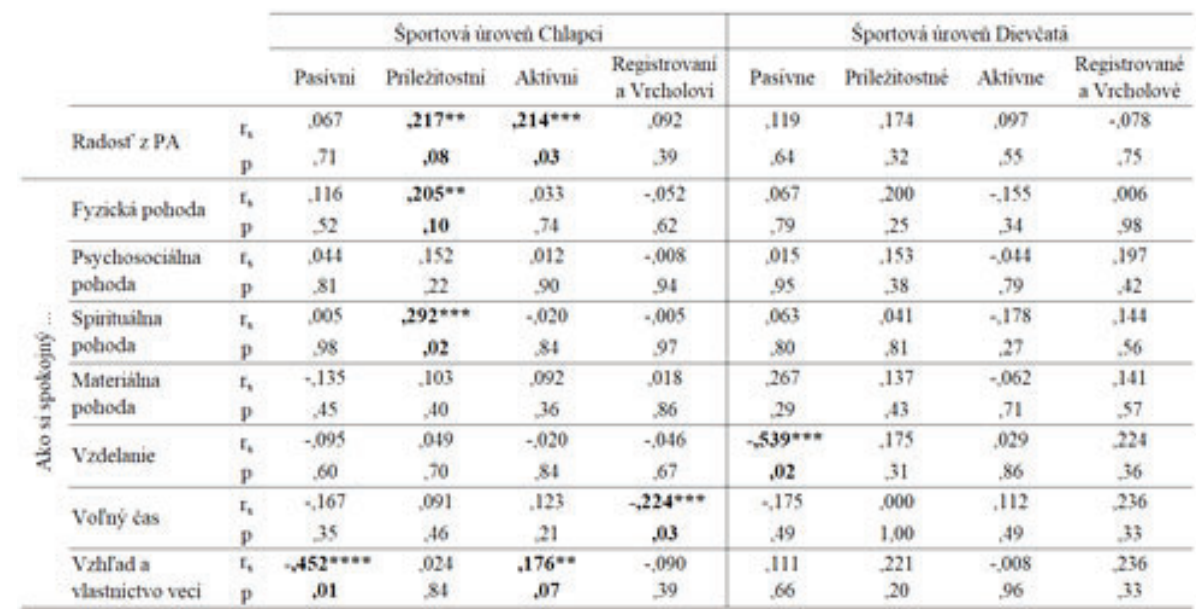

Legenda (Note). (Spearman correlation coefficient rs ; p $<0,20 \star, \mathrm{p}<0,10 \star \star, \mathrm{p}<0,05 \star \star \star, \mathrm{p}<0,01 \star \star \star \star$ )

Tabulka 6./ Table 6 .

Korelácie radosti z pohybových aktivít s oblastami kvality života./ Correlation of joy from movement with areas of quality of life.

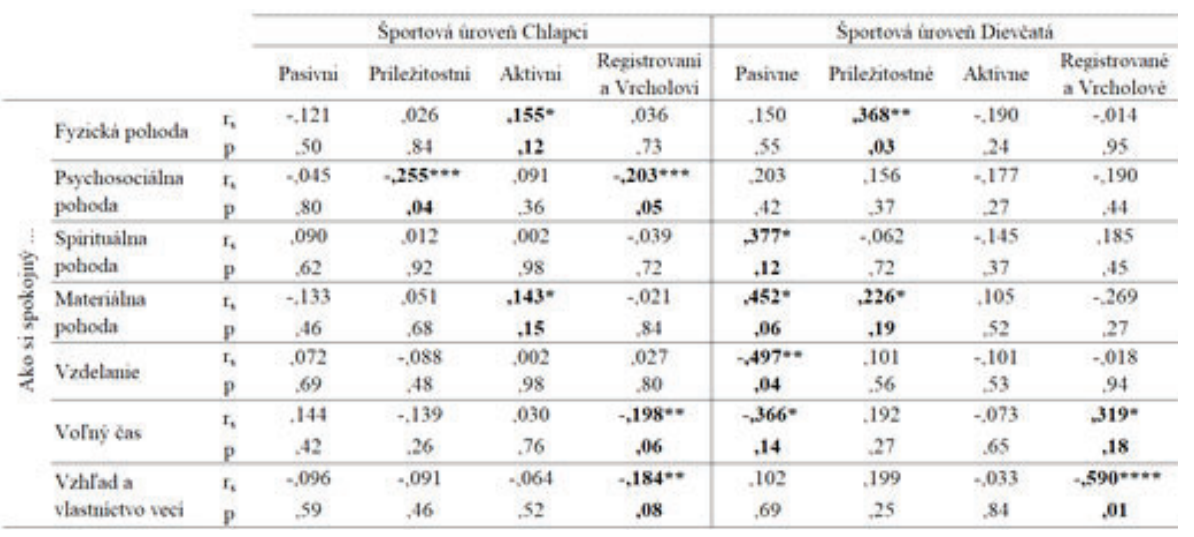

Legenda (Note). (Spearman correlation coefficient rs ; p $<0,20 \star, \mathrm{p}<0,10 \star \star, \mathrm{p}<0,05 \star \star \star, \mathrm{p}<0,01 \star \star \star \star)$

Záporné vzṫah pohybovej aktivity v týždni $\mathrm{k}$ oblasti vzhladu a vlastníctva vecí $\left(\mathrm{r}_{s}=-0,452\right.$ $\mathrm{p}=0,01)$ sa preukázali u skupiny chlapcov s pasívnou športovou úrovňou a k oblasti "volný čas" 
$\left(\mathrm{r}_{s}=-0,224 \mathrm{p}=0,03\right)$ u skupiny chlapcov, ktorí sú registrovaní a vrcholoví športovci. U dievčat nízka úroveň pohybovej aktivity korelovala so vzdelaním $\left(\mathrm{r}_{s}=-0,539 \mathrm{p}=0,02\right)$.

Pozitívne interakcie radosti z pohybu s oblastami kvality života(tab. 6) boli zaznamenané u skupiny chlapcov vykonávajúcich pohybové aktivity aktívne (fyzická pohoda $\mathrm{r}_{s}=0,155 \mathrm{p}=0,12$; materiálna pohoda $\left.\mathrm{r}_{s}=0,143 \mathrm{p}=0,15\right)$. U dievčat zasa vykonávajúcich pohybové aktivity príležitostne (fyzická pohoda $\mathrm{r}_{s}=0,368 \mathrm{p}=0,03$; materiálna pohoda $\mathrm{r}_{s}=0,226 \mathrm{p}=0,19$ ), pasívne (spirituálna pohoda $\mathrm{r}_{s}=0,377 \mathrm{p}=0,12$; materiálna pohoda $\left.\mathrm{r}_{s}=0,452 \mathrm{p}=0,06\right)$, resp. sú registrované a vrcholové športovkyne (volný čas $\mathrm{r}_{s}=0,319 \mathrm{p}=0,18$ ).

Záporné interakcie radosti z realizácie pohybových aktivít s oblastami kvality života boli preukázané u chlapcov vykonávajúcich pohybové aktivity príležitostne (psychosociálna pohoda $\mathrm{r}_{s}=-0,255$ $\mathrm{p}=0,04$ ) a na registrovanej - vrcholovej úrovni (psychosociálna pohoda $\mathrm{r}_{s}=-0,203 \mathrm{p}=0,05$; volný čas $\mathrm{r}_{s}=-0,198 \mathrm{p}=0,06$; vzhlad a vlastníctvo vecí $\left.\mathrm{r}_{s}=-0,184 \mathrm{p}=0,08\right)$. Obdobne skupiny dievčat s pasívnou športovou úrovňou boli preukázané záporné interakcie radosti z pohybu s oblastou vzdelania $\left(\mathrm{r}_{s}=-0,497 \mathrm{p}=0,04\right)$ a volného času $\left(\mathrm{r}_{s}=-0,366 \mathrm{p}=0,14\right)$ i v skupine registrovaných vrcholových športovkýň s oblastou vzhladu a vlastníctva vecí $\left(\mathrm{r}_{s}=-0,590 \mathrm{p}=0,01\right)$.

\section{Diskusia}

V príspevku sme poukázali na úroveň pohybovej aktivity, radosti z pohybových aktivít a subjektívne hodnotenie oblastí kvality života u žiakov a žiačok stredných škôl s rôznou športovou úrovňou vo východoslovenskom regióne Spiš. V porovnaní z celoslovenskými údajmi sú výsledky diferencované a môžeme potvrdit vplyv regionálneho faktoru v prospech chlapcov a nie u dievčat ako doposial' uvádzali celoslovenské prieskumy.

Objem pohybových aktivít chlapcov a dievčat stredných škôl prerozdelených do skupín podla športovej úrovne úzko súvisí so zvyšujúcou sa športovou úrovňou. Z hladiska porovnania oboch pohlaví na rovnakej športovej úrovni je objem pohybových aktivít v týždni rovnaký. V porovnaní s celoslovenskými výsledkami (Brod’áni, Šiška \& Kováčová, 2018a) je objem pohybových aktivít približne na rovnakej úrovni. Nižší objem pohybovej aktivity registrujeme pri porovnaní s výskumom Brod’áni et al. (2018b) iba u dievčat zo Spiša v skupinách aktívnych a registrovaných športovkýň. Týždenný objem pohybových aktivít našej vzorky je však v porovnaní s 15-16 ročnými adolescentami vyšší (Brod’áni, Spišiak \& Paška, 2015) a taktiež v porovnaní so žiakmi v strednej a neskorej adolescencii (Brod'áni, 2012; Brod’áni, Lipárová \& Král, 2016; Kalinková et al., 2015).

Úroveň radosti z pohybových aktivít a úroveň subjektívneho hodnotenia oblastí kvality života medzi zadefinovanými športovými úrovňami a pohlaviami je rovnaký. V porovnaní s celoslovenskými výsledkami (Brod’áni, Šiška \& Kováčová, 2018ab) si však stredoškoláci zospišského regiónu v ovela vyššej miere užívajú radost s vykonávania pohybových aktivít.

U dievčat bola zaznamenaná kongruencia dôležitosti a spokojnosti s oblastami kvality života. U chlapcov sa rozdiely prejavujú sporadicky a to prevažne v skupinách vykonávajúci pohybové aktivity pravidelne alebo z vlastného presvedčenia. Úroveň hodnotenia kvality života vo všetkých oblastiach sa pohybovala v priemere medzi intervalovými škálami „3 stredne dôležité a 4 velmi dôležité”, resp. „3 spokojný(á) niečo medzia 4 spokojný(á)”. Z celoslovenského pohladu žiaci a žiačky stredných škôl vo všetkých vyššie uvádzaných prieskumochprikladajú oblastiam kvality života ovela vyššiu dôležitost ako žiaci a žiačky zo spišského regiónu. Jedná sa hlavne o oblasṫfyzickej, spirituálnej, materiálnej pohody, vol’ného času a orientácie na budúcnosté

Rodové rozdiely v interakciách pohybových aktivít, radosti z pohybových aktivít s kvalitou životanachádzame tentokrát v prospech chlapcov a nie u dievčat ako doposial' uvádzali celoslovenské prieskumy (Brodáni, Šš̌ka Kováčová, 2018ab; Sutka, 2015).Pozitívne interakcie medzi celkovou pohybovou aktivitou v týždni, radostou z pohybových aktivít a oblastami kvality života prevažujú u žiakov vykonávajúcich pohybové aktivity príležitostne a aktívne, čo potvrdzujú aj predchádzajúce prieskumy (Bárta et al. 2018; Bradáčová 2012; Brod’áni 2012; Brod’áni \& Paška 2014; Brod’áni et al., 2015; Brod'áni et al., 2016; Sutka et al., 2013). Minimálny počet pozitívnych interakcií nachádzame v skupinách chlapcov a dievčat vykonávajúcich pohybové aktivity pasívne, resp. v skupinách registrovaných - vrcholových športovcov. Registrujeme však nižší počet záporných interakcií medzi pohybovou aktivitou, radostou z pohybových aktivít a oblastami kvality života ako v predchádzajúcich prieskumoch. 
Radosṫ z pohybu je jeden z hlavných atribútov akejkol’vek volnočasovej aktivity. Zábava, radosta optimálne preživanie sú podla Estesovej \& Hendersonovej (2001) dôležitými aspektmi rekreačných aktivít. Preto môže byt radost’ opísaná ako pozitívny afektívny stav, ktorý reflektuje pocity ako radost a zábavu (Motl et al., 2001).

Doterajšie zistenia priniesli dôkaz o existencii vzţahumedzi fyzickou aktivitou a radostou. Hills \& Argyle (1998) zistili, že l’udia sa dobrovolne zúčastňujúna pohybových aktivitách pre radost’ a to dokonca aj pri takých, ktoré im spôsobujú bolest', akýmije napríklad box. Ďalšie práce a výsledky štúdií (Hills \& Argyle, 1998; Estes \& Henderson, 2001; Motl et al., 2001; Prochaska, Sallis, Slymen, \& McKenzie, 2003; Biddle, Whitehead, O’Donovan, \& Nevill, 2005) poukazujú na skutočnoste, že prežívanie radosti z pohybu je klúčovým faktorom, ktorý motivuje ludívo všetkých obdobiach jeho života k pohybu (Cairney et al., 2012; Goudas \& Biddle, 1993). Radost́je podla Sollára \& Romanovej (2015) pozitívny afektívny stav, ktorý reflektuje také pocity ako sú zábava, potešenie, radoste, nadšenie. Rovnako je podla nich radost vnímaná ako jeden z významným determinantov pohybovej aktivity. Radost́ z pohybovej aktivity ako jeden z klúčových činitelov, ktorý sa podiela na participácii a zotrvaní jedinca pri konkrétnej telesnej aktivite. Sallis, Prochaska, \& Taylor (2000) skúmali 22 vybraných korelátov telesnej aktivity u školopovinných detía zistili, že napríklad radosṫ z hodín telesnej výchovy bola silným prediktorom telesnej aktivity v neskoršom veku. A ukazuje sa, že aj významným faktorom s prepojením na jednotlivé oblasti kvality života.

Na základe klasifikovania jednotlivých vzṫahov sledovaného konštruktu pohybová aktivita, radost’ z pohybu a kvalita života, môžeme poukázat na problematické oblasti kvality života žiakov stredných škôl a na možnosti ich zlepšovania prostredníctvom inovatívnych prístupov v oblasti zážitkovej pohybovej aktivity, telesnej a športovej výchovy, resp. mimoškolských aktivít. ${ }^{1}$

\section{Literatúra}

Antaramian, S. P., Huebner, S. E., \& Valois, R. (2008). Adolescent Life Satisfaction. Applied Psychology, 57(1), 112-126.

Barnett, L., Cliff, C., Morgan, P., Van Beurden, E. (2013). Adolescents' perception of the relationship between movement skills, physical activity and sport. European Physical Education Review Volume, $19(2), 271-285$.

Bárta, M., Kanásová, J., Kalinková, M., Šiška, L. (2018). Physicalactivity and interaction of joy from physical activity to individually areas of lifequality of adolescents. In J. Brod’áni (Ed.), Sport a recreation 2018 (pp. 203-213). Nitra: CPU.

Blatný, M. (2001). Osobnostní determinanty sebehodnocení a životní spokojenosti: mezipohlavní rozdíly. Ceskoslovenská psychologie, 45(5), 385-392.

Biddle, S. J., Whitehead, S. H., O’Donovan T. M., \& Nevill, M. E. (2005). Correlates of participation in physical activity for adolescent girls: a systematic review of recent literature. Journal of Physical Activity 83 Health, 2(4), 423.

Bradáčová, N. (2012). Vzt’ah pohybovej aktivity a subjektívnej pohody u adolescentov. In L. Chovanec (Ed.), Śtudentská vedecká, odborná a umelecká činnost’ (pp. 186-197). Bratislava, Slovakia: UK.

Brodáni, J., \& Paška, L. (2014). The quality of life of adolescents in relation to preferred type of sport. In P. Schickhofer (Ed.), Sports, physical activity and health - International scientific conference (pp. 65-75). Bratislava : Slovak Scientific Society for Physical Education and Sports.

Brodáni, J. (2012). Sport activity level and the lifequality of adolescents. Acta Universitatis Matthiae Belii, Physical Education and Sport, 4(1), 33-41.

Brod’áni, J., Spišiak, M., \& Paška, L. (2015). The interaction of physical activity and quality of life of adolescents. Journal of Physical Education and Sport, 15(3), 518-524.

Brodáni, J., Lipárová, S., \& Král, M. (2016). The interaction of physical activity and the life quality of students in mid and late adolescence. Physical Activity Review, 4(1), 124-131.

Brodáni, J., Šiska, L., \& Kováčová, N. (2018a). Interaction of physicalactivity, joy of physicalactivity and quality of life of highschoolstudentswithdifferent level of sportperformance. International Journal of PhysicalEducation, Sports and Health, 5(4), 12-18.

\footnotetext{
${ }^{1}$ The paper is part of grant MŠ SR KEGA 003UKF-4/2016.
} 
Brodáni, J., Šiska, L., \& Kováčová, N. (2018b). Differences in physical activity, joy of movement and quality of life of boys and girls from secondary schools. In A. Hubinák (Ed.), Current problems of physical education and sports VII (pp. 25-35). Ružomberok, Slovakia: VERBUM.

Cairney, J., Kwan, M. Y., Velduizen, S., Hay, J., Bray, S. R., \& Faught, B. (2012). Gender, perceived competence and theen joyment of physical education in children: a longitudinal examination. International Journal of Behavioral Nutrition and Physical Activity, 9(1), 26.

Dragomirecká, E. (2006). SQUALA Subjective quality of life analysis: př́ručka pro uživatele české verze dotazniku subjektivni kvality života SQUALA. Praha: Psychiatrické Centrum.

Estes, C., \& Henderson, K. (2001). Enjoyment and the good life. Parks and Recreation, 38(2), 22-31.

Gill, D. L., Hammond, C. C., Reifsteck, E. J., Jehu, C. M., Williams, R. A., Adams, M. M., Lange, E. H., Becofsky, K., Rodriguez, E., \& Shang, Y. T. (2013). Physical Activity and Quality of Life. Journal of Preventive Medicine and Public Health, 46(1), 28-34.DOI:10.3961/jpmph.2013.46.S.S28

Goudas, M. \& Biddle, S. J. H. (1993). Pupil perceptions of enjoyment in pysical education. Physical Education Review, 16(2), 145-150.

Heesch, K. C., Masse, L. C., \& Dunn, A. L. (2006). Using Rasch modeling to re-evaluate three scales related to physical activity: enjoyment, perceived benefits and perceived barriers. Health Education Research, 21(1), 58-72.

Hills, P. \& Argyle, M. (1998). Positive moods derived from leisure and their relationship to happiness and personality. Personality and individual differences, 25(3), 523-535.

Kalinková, M., Brodáni, J., Kanásová, J., Paška, L., Šutka, V. (2015). The influence of physical activities on the quality of life of adolescents. Sport Science, 8(1), 17-23.

Levin, J. S. \& Chatters, L. M. (1998). Religion, health, and psychological well-being in older adults. Journal of Aging and Health, 8(10), 504-531.

Motl, R. W., Dishman, R. K., Saunders, R., Dowda, M., Felton, G., \& Pate, R. R. (2001). Measuring enjoyment of physical activity in adolescent girls. American journal of preventive medicine, 21(2), $110-117$.

Norris, R., Carrol, D., \& Chochrane, R. (1992). The effects of physical activity and exercise training on psychological stress and well-being in an adolescent population. Journal of Psychosomatic Research. $36(1), 55-65$.

Ocetková, I. (2007). Úloha spirituality v životní pohodě a kvalite života mladých lidí. (Dizertačná práca, Brno: Masarykova univerzita, Ceská republika). Retrieved from https://is.muni.cz/th/kjjxm/

Ojiambo, R. M. E. (2013). Physical Activity and Well-being: A Review of the Health Benefits of Physical Activity on Health Outcomes. Journal of Applied Medical Sciences, 2(2), 69-78.

Prochaska, J. J., Sallis, J. F., Slymen, D. J., \& McKenzie, T. L. (2003). A longitudinal study of children's enjoyment of physical education. Pediatric Exercise Science 15, 170-178.

Rank, M., Wilks, D. C., Foley, L., Jiang, Y., Langhof, H., Siegrist, M., \& Halle, M. (2014). Healthrelated quality of life and physical activity in children and adolescents 2 years after an inpatient weight-loss program. The Journal of Pediatrics, 165(4), 732-737.

Romanová, M. \& Sollár, T. (2015). Physical activity level, substanceuse and enjoyment of physical activity in adolescence and early adulthood. In J. Brod'áni (Ed.), Movement and quality of life 2015 (pp. 126-131). Nitra, Slovakia: CPU.

Romanová, M. \& Sollár, T. (2016). Perceived sport competence, actual norm of physical activity and enjoyment of physical activity in adolescence. In J. Brodáni (Ed.), Sport a recreation 2016 (pp. 5-13). Nitra, Slovakia: UKF.

Romanová, M. \& Sollár, T. (2017). Identification of gender differences in motivation for physical activity in high school students. In J. Brodáni (Ed.), Sport a recreation 2017 (pp. 72-78). Nitra, Slovakia: CPU.

Romanová, M. \& Sollár, T. (2018). Relationships between Physical Activity, Motivation for Physical Activity and Body Attitudes in Adolescents In J. Šimonek (Ed.), Sport Science in Motion Proceedings from scientific conference (pp. 185-193). Komárno, Slovakia: University J. Selyeho.

Sallis, J. F., Prochaska, J. J., \& Taylor, W. C. (2000). A review of correlates of physical activity of children and adolescents. Medicine and science in sports and exercise, 32(5), 963-975.

Sigvartsen, J., Gabrielsen, L., Abildsnes, E., Stea, T. H., Omfjord, Ch. S., \& Rohde, G. (2016). Exploring there lationship between physicalactivity, lifegoals and health-related quality of life among 
high school students: a crosssectional Study. BMC Public Health. 16, 709. DOI 10.1186/s12889016-3407-0

Sollár, T., \& Romanová, M. (2015). Developmental specificities and gender differences in enjoyment of physical activity in adolescence and early adulthood. In J. Brod’áni (Ed.), Movement and quality of life 2015 (pp. 78-82). Nitra Slovakia: CPU.

Sollár, T., \& Romanová, M. (2016). Social support, parental support and enjoyment of physical activity in adolescence. In J. Brodáni (Ed.), Sport a recreation 2016 (pp. 38-45). Nitra, Slovakia: CPU.

Sollár, T., \& Romanová, M. (2017). Motivation for physical activity in high school and university students. In J. Brod’áni (Ed.), Sport a recreation 2017 (pp. 93-99). Nitra, Slovakia: UKF.

Sollár, T., \& Romanová, M. (2018). GenderDifferences in PhysicalActivity, MotivationforPhysicalActivity and Body Attitudes in Adolescence. In J. Simonek (Ed.), SportScience in Motion Proceedingsfromscientificconference (pp. 194-202). Komárno, Slovakia: University J. Selyeho.

Stevens, S. (2017). Thejoy of movement in physical education: theen fleshed body. (Dissertation work, Canterbury, University of Canterbury, New Zeland). Retrieved from http://hdl.handle.net/10092/ 14910

Sýkorová, Z. \& Blatný, M. (2008). Kvalita života u adolescentov. Brno: Masarykova univerzita.

Sutka, V., Brodáni J., Špániková, V., \& Vravková, M. (2013). Physical Activity and Life Quality of Students on Constantine the Philosopher University in Nitra. Journal of International federtion Physical Education. FIEP Bulletin, 83(3), 51-53.

Sutka, V. (2015). Improving the quality and health of adolescents by means of physical activity at elementary and high schools. Final report of the KEGA 014UKF-4/2013 grant. Nitra: CPU.

Valášková, M., Ježko, S., \& Macek, P. (2002). Changes of body image during adolescence: relationship to self-esteem and self-efficacy: Poster presented at the 8th Biennial Conference of the European Association for Research on Adolescence, September 3rd - September 7th 2002, Oxford.

Vašíčková, J. Groffik, D., Frömel, K., Chmelík, F., \& Wasowicz, W. (2013). Determining gender differences in adolescent physical activity level susing IPAQ long form and pedometers. Annals of Agricultural and Environmental Medicine, 20(4), 749-755.

Vilhjalmsson, R. \& Kristjansdottir, G. (2003). Gender differences in physical activity in older children and adolescents: the central role of organized sport, 56(2),363-74.

Zannotti, M., \& Pringuey, D. (1992). A method for quality of life assessment in psychiatry: the SQUA-L-A (Subjective Quality of life Analysis). Quality of life News Letter, 4(6).

doc. PaedDr. Jaroslav Brod’áni, PhD.

Univerzita Konštantína Filozofa v Nitre

Tr. A. Hlinku 1, 949 74, Nitra

jbrodani@ukf.sk 